DOI 10.37882/2223-2982.2020.09.08

\title{
УКРАИНСКАЯ ИДЕОЛОГИЯ В КРЫМУ В ПЕРИОД КОНЦА 1917 - НАЧАЛА 1919 ГГ.
}

\section{UKRAINIAN IDEOLOGY IN THE CRIMEA FROM LATE 1917 TO EARLY 1919}

A. Butovskiy

Summary: The article is devoted to the complex issue of Ukrainian ideology in the Crimea from late 1917 to early 1919. Based on a thorough analysis of sources, the author offers to consider the history of the development of Ukrainian agitation and propaganda in this difficult period of the country's history. According to the researcher, the basis of «Ukrainianism» was the direct hope of the population that the «Ukrainianized» regiments, divisions and corps formed at the front and in the rear would be able to maintain relative order in the South of Russia, keep the country from sliding towards revolutionary anarchy and lawlessness. However, these aspirations were in vain. The Ukrainian regiments and battalions created in the Taurida Governorate directly sided with the Bolsheviks. As for the main mistakes of Ukrainian propaganda on the territory of the Peninsula, they consisted in its rather strong nationalist demagogic slogans that alienated the multi-ethnic population of Crimea.

Keywords: Civil war, propaganda, agitation, Russia, Germany, Ukraine, Crimea, Black Sea Fleet.

\author{
Бутовский Александр Юрьевич \\ К.п.н., дочент, ФГБОУ ВО «Тульский государственный \\ педагогический университет им. Л.Н. Толстого» \\ mrvip76@mail.ru
}

Аннотация: Статья посвящена сложной теме украинской идеологии в Крыму в период конца 1917 - начала 1919 гг. На основе тщательного анализа источников, автор предлагает рассмотреть историю развития украинской агитации и пропаганды в указанный сложный период истории нашей страны. По мнению исследователя, базой «украинства» стала прямая надежда населения на то, что сформированные на фронте и в тылу «украинизированные» полки, дивизии и корпуса, будут способны поддержать относительный порядок на Юге России, удержать страну от сползания в сторону революционной анархии и беспредела. Но все эти чаяния, оказались напрасными. Украинские полки и батальоны, созданные в Таврической губернии, прямо переходили на сторону большевиков. Что же касается основных ошибок украинской пропаганды на территории полуострова, то они заключались в ее довольно сильных националистических демагогических лозунгах, оттолкнувших от себя многонациональное население Крыма.

Ключевые слова: Гражданская война, пропаганда, агитация, Россия, Германия, Украина, Крым, Черноморский флот.

истории нашей страны.

Впервые, с таким явлением, как украинская агитация и пропаганда, жители полуострова столкнулись еще в 1917 году. Причём, сразу же можно говорить о ее определенном успехе, так как в декабре этого года на линкоре «Воля» демонстративно был поднят украинский флаг. Правда, активные протестные действия матросов корабля, из которых 300 человек считали себя русскими, а 400 украинцами, не позволили закрепить успех украинской пропаганды. Матросы пригрозили покинуть корабль и на последующем собрании комитетов, было решено спустить на «Воле» украинский флаг и вновь поднять красный [7, с. 238].

Первые неудачи совершенно не смутили националистов, политические аппетиты которых продолжали расти. Теперь они претендовали не только на Черноморский флот и Крым, но и на северные уезды Таврической губернии. Люди, которые в этот момент возглавили самопровозглашенную Украину, были готовы пойти на соглашение даже с Советской Россией в обмен на Крым и флот, включая торговый, который, по их словам, «на Черном море принадлежит только Украине» [19, с. 14-16]. В дальнейшем, по этой же причине, украинскими властя- 
ми была выбрана пропагандистская тактика полного игнорирования Республики Таврида. В Крым пошли телеграммы и письма из различных, только что образованных ведомств Украины. Так как, все эти документы были юридически ничтожные, появление их в Крыму более походило на пропагандистскую акцию, чем на действия, по какому-то ни было, государственному управлению. Для примера, можно привести указание управляющему государственной Таврической конюшни, в категорической форме сменить все надписи и перевести делопроизводство на украинский язык [ГААРК Ф.Р-1694. Оп.1. Д.96. Л.7], или письмо из отдела православной церкви Департамента исповеданий Украины «Губернияльному комиссару», который должен был «пристально наблюдать, чтобы духовенство исполняло распоряжения о поминании на службе Божьей по церквям Государство и Власть Украинскую» [ГААРК Ф.Р-1694. Оп.1. Д.96. Л.8; 7, с. 338].

Особый интерес для нас, представляет пропагандистский шаблон украинских сепаратистов, призванный оправдать перед населением южных российских губерний присоединение их территорий к самопровозглашенной Украине. Так, исходя из логики националистов, численность крымско-татарского народа не способствует к созданию самостоятельной государственной организации и поэтому они должны опереться на какое-нибудь сильнейшее государство, котором может быть только Украина. Кроме того, по мнению сепаратистов, Крым был связан географически, политически и экономически не с Россией, а именно с Украиной. «Украина - страна хлебная с огромными промышленными возможностями в будущем, - крымский юг - это Ривьера, климатические станции, виноградные и фруктовые сады, которые, однако, без украинских промышленных изделий обойтись не смогут. Государственный симбиоз крымских татар и украинцев продиктован самой природой, и мы думаем, что эти резоны, как наиболее убедительные, примут во внимание татарские политики и создадут добро для родной страны - выгодное для украинцев и себя согласие» $[19$, c. 14].

Надо сказать, что на определенных этапах такая агитация имела успех, тем более, что на подобную пропаганду накладывалась вера в основном городского, населения об освобождении украинцами Крыма, не только от большевиков, но и от немцев. Информация о том, что украинские «освободители», отставали от германских войск на двое суток, старательно замалчивалась. Не говоря уже о том, что украинские войска полковника Болбочана были в течение нескольких последующих дней, вообще выдворены из Крыма [22, с. 87; 25, с. 93; 14, с. $417-$ $418 ; 16$, c. $92 ; 27$, s. $384 ; 26$, s. 89 ].

Тем не менее, «Уряд» Гетмана П. Скоропадского для оправдания предполагаемого присоединения Крыма к Украине продолжил придумывать различные идеологи- ческие ухищрения и пропагандистские уловки. Их основой продолжали оставаться откровенно ложные, искаженные или специально недосказанные политические, географические и экономические категории, с помощью которых российскому населению, настойчиво внушалась мысль, что Севастополь и Черноморский флот, должны принадлежать исключительно недавно возникшей Украине. Такая пропаганда иногда подкреплялась и реальными политическими акциями, как это, например, произошло 26 мая (8 июня) 1918 года в г. Перекопе. В этот день сюда прибыли люди, гордо называющие себя украинской военной комендатурой. Председателю уездной земской управы было заявлено, что Перекоп и находящаяся к северу от него часть уезда на протяжении 5 тысяч десятин земли, принадлежащих городу, теперь относятся к Украине [15, с. 60-61]. Причём к концу месяца, в качестве гарнизона к Перекопу был подтянут 3-й конный дивизион корпуса украинской морской пехоты. Совсем недалеко, в Николаеве и Александровске была сосредоточена одна из немногих боеспособных украинских частей - Запорожский корпус, недавно выведенный из Крыма [14, с. 418]. Кроме гражданских властей в трех северных уездах Таврической губернии создавалась военная инфраструктура, подчиненная, как и прежде штабу Одесского военного округа. Правда уже 10(23) июня Перекопский уездный староста Пётр Евгеньевич Вильнер, Евпаторийский уездный староста Владимир Николаевич Байдак и Симферопольский уездный староста Николай Владимирович Благановский, вместе с их администрациями, были переведены в Симферополь и прикомандированы к уполномоченному при 52-м германском корпусе А.В. Десницкому [4].

Такое внимание к полуострову со стороны самопровозглашенной Украины, отчасти объясняется личным болезненным отношением к данной проблеме германского ставленника П.П. Скоропадского. В своих мемуарах гетман писал про Крым, что «немцы не прочь там утвердиться. Турция с татарами тоже протягивает к Крыму руки. Украина же не может жить, не владея Крымом, это будет какое-то туловище без ног. Крым должен принадлежать Украине, на каких условиях, это безразлично, будет ли это полное слияние или широкая автономия, последнее будет зависеть от желания самих крымцев, но нам надо быть вполне обеспеченными от враждебных действий со стороны Крыма. В смысле же экономическом Крым фактически не может существовать без нас. Я решительно настаивал перед немцами о передаче Крыма, на каких угодно условиях, конечно, принимая во внимание все экономические, национальные и религиозные интересы народонаселения. Немцы колебались, я настаивал самым решительным образом» [20, с. 262 ].

Вскоре пропагандистские домыслы П.П. Скоропадского, сделали следующий шаг в своем развитии, стремясь всеми возможными и невозможными доводами 
оправдать захват Крыма у ослабевшей России. Так в своем письме германскому послу Мумму от 10 мая 1918 года, гетман написал, что «особое значение, для возрождения Украины имеет установление ее границ, особенно южной, и, таким образом, овладение Крымом. Присоединение Крыма имело бы то значение для Украинской Державы, что она была бы обеспечена продуктами первой необходимости, как соль, табак, вино и фрукты ... Владение Крымом дало бы еще и возможность сберечь на Украине много средств, организуя новые и отстраивая старые курорты. Кроме того, владея южным берегом Крыма, Украина получила бы такие природные порты, как Севастополь и Феодосия. Без Крыма Украина была отрезана от Черного моря, ибо она могла бы распоряжаться только одним портом в Николаеве, так как Одесса давно сильно перегружена. Таким образом, Украина без Крыма стать сильной державой не могла бы, особенно, с экономической стороны. Так неестественно отрезанная от моря Украина должна бы обязательно усиливать стремление к захвату этого морского побережья и, вместе с тем, обострились бы отношения с тем государством, которому было бы передано владение Крымом. Тем более что с этнографической стороны было бы неоправданным существование планируемого татарского государства, ибо татары составляют не более $14 \%$ крымского населения» [6, с. 146].

На этой волне агитации и пропаганды 31 мая (12 июня) Украинское правительство решает обратиться с нотой к германскому послу с требованием присоединения Крыма к Украине. Однако текст этого документа фактически превращает это действие, не в серьезный политический акт, а в пропагандистскую акцию с плохо подготовленным сценарием.

Для начала заявлялось, что Крым был присоединен к России, не только усилиями русских, но и украинцев, кроме того, «монархический» режим М. Сулькевича, усилил «желание значительной части населения Крыма присоединиться к Украине», особенно татар, которые «больше тяготеют к украинцам» [17, с. 85]. При этом правительство М. Сулькевича, якобы отказывается вести переписку на украинском языке и преследует украинские организации и газеты в Крыму [20, с. 260-264]. Последнее являлось прямой ложью. Ни одного факта преследования не было, мало того Украинские организации, Просвиты и кооперативы продолжали работать [ГААРК. Ф. Р-999. Оп. 2. Д. 402. Л. 190; 7, С. 381-382; 18, с. 288-292; 5, с. 187-188]. Насчет газет - ни одной газеты на украинском языке на территории Крыма так и не вышло. Один из самых серьезных украинских специалистов по истории периодической печати в период Гражданской войны на Украине и в Крыму профессор Н.В. ЯблоноУвська, настойчиво искала, но так и не нашла в Крыму с 1917 по 1921 г. ни одной украино-язычной или проукраинской газеты, о чем честно и говорит в своих работах - да день- ги выделялись, но газеты не издавались ... потому что не было денег [23, с. 5-10].

Но, тем не менее, для людей провозгласивших независимость Украины выглядело логично, что когда «украинские войска, с помощью дружеской нам германской армии захватили Крым в свои руки, встал вопрос о присоединении Крыма к Украинской державе», «присоединение Крыма может состояться на автономных началах, в связи, с чем будет разработан соответствующий проект; зная настроение значительного большинства населения Крыма, имея в виду интересы этого населения и его давние связи с Украинским правительством, не имея сомнений, что воля населения Крыма может быть выражена только за соединение с Украиной» [6, с. 147].

А.Г. Зарубин и В.Г. Зарубин не могли обойти вниманием этот, с многих сторон, интересный текст украинской ноты, указав на несоответствие его содержания с действительностью. На самом деле, никто не опрашивал в это время население Крыма, не существовало никаких давних связей его с Украинским правительством, как и не было никакой воли населения полуострова за соединение с Украиной [7, с. 378]. Перед нами самая настоящая пропагандистская поделка откровенно лживого характера, призванная скрыть реальные причины настойчивого стремления прогерманских украинских сил присоединения Крыма к Украине. В этой связи, по нашему мнению, необходимо более внимательно отнестись к словам управляющего министерством иностранных дел Украины Д.И. Дорошенко, который выразил крайнюю обеспокоенность «иметь под рукой какой-нибудь Пьемонт для возрождения единой и неделимой России», тем более выпустить из рук Севастополь, эту «базу для украинского флота и ключ для господства на Черном море» $[6$, с. 145].

Несмотря на то, что немцы, которые, безусловно, имели свои, далеко идущие планы на полуостров, только намекали, что может быть, когда-нибудь, они передадут часть Черноморского флота Украине, последняя продолжала вести свою пропагандистскую кампанию на этот счет. Так, украинские представители постоянно лоббировали финансирование Морского министерства и украинскую морскую администрацию в Севастополе. Десятого июня 1918 г. Совет министров Украинской державы, даже утвердил постановление об отпуске в распоряжение Морского министра 1 млн. гривен, которые должны были пойти на нужды Севастопольского морского порта [3]. И это несмотря на скудность средств, и того обстоятельства, что, условно согласные служить в украинском Черноморском флоте В.Е. Клочковский, Н.И. Черниловский-Сокол, и С.И. Бурлей, кроме учета кадров, более ничем в Севастополе не занимались. Причём все трое, как и большинство их офицеров, начиная с лета 1918 года, начали поступать на службу частью в Краевой, 
частью в Добровольческий флот [14, с. 442].

Также настойчиво министерство иностранных дел Украинской Державы продолжало выделять средства на поддержку трех газет на полуострове, которые должны были пропагандировать идею инкорпорации Крыма в состав Украины. Одной из таких газет руководил киевский журналист Е.А. Ганейзер, перевозивший в Крым деньги на подобные издания, хотя, как уже говорилось выше, ни одно из них, так и не вышло. Е.А. Ганейзер стал известен также тем, что по просьбе В.С. Налбандова доставил на полуостров документ о соединении Крыма с Украиной под управлением наместника гетмана, каковым должен быть стать М.А. Сулькевич. Однако последний отказался от такого щедрого предложения, хотя и готов был начать переговоры и пойти на ряд уступок Украине [7, с. 381].

Тем не менее, несмотря на неудачи, украинское министерство иностранных дел продолжало выделять деньги на пропагандистские акции, из которых особо следует отметить финансирование специально основанного для ведения на полуострове проукраинской пропаганды «Комитета Степной Украины» [8, с. 65]. Впрочем, П.П. Скоропадский весьма скептически оценивал деятельность подопечных Д.И. Дорошенко: «...министерство иностранных дел повело за свой риск и страх довольно наивную украинскую агитацию, какие-то молодые люди в украинских костюмах в Ялте и в окрестных городках убеждали публику сделаться украинцами. Это не имело, конечно, успеха, но и никому не вредило» [20, с. 262].

Следует также иметь в виду, что 28-29 августа 1918 года состоялся краевой съезд представителей всех украинских национальных организаций и партий. На нем была избрана Крымская краевая рада, вступившая, однако, в оппозиционный гетману П.П. Скоропадскому Украинский Национальный Союз. Члены рады, разумеется, также способствовали распространению идеи присоединения Крыма к Украине. Однако Краевое правительство всячески препятствовало украинской пропаганде в Крыму. Реагируя на такие действия крымской власти, 7 июля 1918 люди стоявшие во главе Украины, ввели запрет на ввоз продовольственных товаров в Крым [5, с. 187-188], что вошло в историю как Крымско-Украинская таможенная война [7, с. 381-382].

Известен пока единственный случай, но знаковый и серьёзный, когда можно говорить об относительном успехе украинской пропаганды в Крыму. В начале февраля 1919 г. переброшенный с Тамани на Перекоп 9-й Кубанской пластунский батальон Крымско-Азовской Добровольческой Армии, глухо забродил, а затем вообще отказался выдвигаться в Северную Таврию. Предлог отказ воевать с «братьями - украинцами» из состава Войск УНР. И хотя перед ними находились подразделения атамана Н. Махно и войска 2-й Украинской Советской армии, таманцы упорно стояли на своем и отказывались драться с «петлюровцами». Поэтому командованию пришлось выполнить их требования и отправить обратно на Кубань [2, с. 130; 1, с. 78]. Но нужно подчеркнуть, что батальон распропагандирован был своими собственными Кубанскими самостийниками (предками таманских казаков были в основном Запорожские казаки), кроме того, сыграла роль усталость от войны, которую таманцы вели с большевиками с мая 1918г. Так что Крымские украинские организации к этому «успеху» не имели никакого отношения.

Таким образом, очевидно, что если в 1917-1918 гг. и имелся некоторый успех среди населения Крыма пропаганды «украинства», то он основывался совсем не на национальных мотивах. Его базой стала прямая надежда населения на то, что сформированные на фронте и в тылу «украинизированные» полки, дивизии и корпуса, способны поддержать относительный порядок на Юге России, удержать страну от сползания в сторону революционной анархии и беспредела. Но все эти чаяния, оказались напрасными. Украинские полки и батальоны, созданные в Таврической губернии, например 4-й украинский батальон И.Ф. Федько в Феодосии, прямо переходили на сторону большевиков.

Что же касается основных ошибок украинской пропаганды на территории полуострова, то они заключались в ее довольно сильных националистических демагогических лозунгах, оттолкнувших от себя многонациональное население Крыма. Именно неуемное стремление увлечь здравомыслящих людей, объявлением всего неукраинского населения Крыма «национальным меньшинством», поголовным переходом на украинский язык, вместе с распространением рассказов о Великой Украине от Дуная до Каспия, полностью провалило всю украинскую агитация и пропаганду, рассчитанную на идеологическую подготовку населения южных российских губерний к появлению на их землях Украинской державы.

\section{ЛИТЕРАТУРА}

1. Борьба за Советскую власть в Крыму в 2 т. Т. 2: Борьба трудящихся Крыма против иностранной военной интервенции и контрреволюции в годы гражданской войны. (Май 1918 г. - ноябрь 1920 г.) / Ред. коллегия: канд. ист. наук М. М. Максименко (отв. ред.) и др. - Симферополь: Крымиздат, 1961. - 364 с. 
2. Деникин А.И. Очерки русской смуты в 5 т. Т. 3: Белое движение и борьба Добровольческой армии: Май-октябрь 1918 г. - Берлин: Слово, 1924. - 272 с.

3. Державний Вістник Кіив. - 16. 06.1918г. - № 15.

4. Державний Вістник. Кіив. - 18.07.1918. - № 23.

5. Діденко І.О. Боротьба за приєднання Криму як прояв соборницької політики Української Держави (1918 р.) // Соборність як чинник українського державотворення (до 90-річчя Акту злуки) Всеукраїнська наукова конференція. Київ, 21 січня 2009 р. - Київ: Поліграф. НАН України, 2009. - С.183-196.

6. Дорошенко Д.І. Історія України, 1917-1923 рр. Т. 2: Українська Гетманська Держава 1918. року. Документально-наукове видання / Упоряд.: К.Ю. Галушко. - Київ: Темпора, 2002. -352 с.

7. Зарубин А.Г., Зарубин В.Г. Без победителей. Из истории Гражданской войны в Крыму. 2-е изд., испр.и доп. - Симферополь: АнтиквА, 2008.- 728 с.

8. Іванець А.В. Нариси діяльності українських політичних партій в Криму (XX століття) // Ученые записки Симферопольского государственного университета. - Симферополь, 1998. - № 6(45). - С. 64-69.

9. Королев В.И. Бунт на коленях: (Политические партии в Таврической губернии. 1905-1907). - Симферополь: Таврия,1993а. - 71с.

10. Королев В.И. Возникновение политических партий в Таврической губернии. 1905-1917гг. - Симферополь: Таврия, 19936. - 42с.

11. Королев В.И.Таврическая губерния в революциях 1917 года: политические партии и власть. - Симферополь:[б.и.],1993в. - 86с.

12. Королев В.И. Черноморская трагедия: Черноморский флот в политическом водовороте 1917-1918 гг. - Симферополь: Таврия, 1994. - 38 с.

13. Королев В.И. Крым и Северная Таврия в 1907-1917 гг.: Страницы политической истории. Симферополь: Таврия, 1995. - 72 с.

14. Крип'якевич І., Гнатевич Б., Стефанів 3., Думін 0., Шрамченко С. Історія Українського війська (від княжих часів до 20-х років XX ст.) / Упорядник Б.3. Якимович. 4-те вид., змін. і доп. - Львів: Світ, 1992. - 713 с.

15. Мальгин А.В. Внешняя политика Крымского Краевого правительства генерала Сулькевича // Крымский музей. - Симферополь, 1994. - №1. - С. 56-66.

16. Надинский П.Н. Очерки по истории Крыма. 1957. Ч. ІІ. Крым в период Великой Октябрьской социалистической революции, иностранной интервенции и гражданской войны (1917-1920 годы). - Симферополь: Крымиздат, 1957. - 303 с.

17. Проданюк Ф. Україньска держава та їі гетман Павло Скоропадский// Військо Україні. - 1993. - №10. - С. 79-91.

18. Сергійчук В. Кримська політика Павла Скоропадського // Гетьман Павло Скоропадський та Українська Держава 1918囚року: наук. 36., присвяч. 125-річчю від народження Гетьмана Павла Скоропадського, та 80-річчю проголошення Української Держави 1918Шр. - Київ, 1998. - С. 14-16.

19. Сергійчук В. Етнічні межі і державний кордон України. Вид. 3-є, доповнене. — Київ: ПП Сергійчук М.І., 2008. — 560 с.

20. Скоропадский П. Воспоминания: конец 1917 года по декабрь 1918 года // Спогади. Кінець 1917 - грудень 1918. - Київ; - Філадельфія, 1995. - 493 с.

21. Хоменок 0.С. Дореволюционная периодическая печать Таврической губернии (1838-1916): очерк истории и библиографический указатель. - 0десса: АО Бахва, 2003. -180 c.

22. Хроника революционных событий в Крыму. 1917-1920гг. /составители И.П. Кондранов, В.А. Широков и др. - Симферополь: Крым, 1969. - 190 с.

23. Яблоновська Н. Зародження української преси Криму (з історії питання) // Журналістика: Наук. 36. - Київ, 2005. - Вип. 5. - С. 5-10.

24. Яблоновська Н.В. Етнічна пресса Криму: історія та сучасність. Монографія.-Сімферополь: Кримське навчально-педагогічне державне видавництво, 2006. $-312 \mathrm{c}$.

25. Якимович Б.3. Збройні сили України. Нарис історії. - Львів: Ін-тут українознавства ім І.Крипьякевича, 1996. - 360 с.

26. Das Landwehr - Infanterie - Regiment 53 im Weltkrieg. 1914-1918. Regimentsgefchichte berfabt an hand der Aften des Regiment von 0tto Koch. [Kettwig] [u.a.], [Flothmann], 1928. $-93 \mathrm{~s}$.

27. Der Weltkrieg 1914 bis 1918. Im Auftrage des Oberkommandos des Heeres bearbeitet und herausgegeben von der Kriegsgeschichtlichen Forschungsanstalt des Heeres. Die militärischen Operationen zu Lande Dreizehnter Band. Die Kriegführung im Sommer und Herbst 1917. Die Ereignisse außerhalb der Westfront bis November 1918. - Berlin im Jahre, 1942. - XVI, 483 S. + 27 Kt., 8 BI.

(с Бутовский Александр Юрьевич (mrvip76@mail.ru). 